\title{
Plant-and Animal-Based Protein Sources for Nutritional Boost of Deep-Fried Dough
}

\author{
Ndamulelo Mudau ${ }^{1}$, Khuthadzo Ramavhoya ${ }^{1}$, Oluwatoyin O. Onipe ${ }^{1}$ and \\ Afam I. O. Jideani ${ }^{1,2 *}$ \\ 1 Department of Food Science and Technology, Faculty of Science Engineering and Agriculture, University of Venda, \\ Thohoyandou, South Africa, ${ }^{2}$ Post-Harvest Handling Group, ISEKI-Food Association, Vienna, Austria
}

\section{OPEN ACCESS}

Edited by: Fatih OZOGUL,

Çukurova University, Turkey

Reviewed by:

Cengiz Gokbulut,

Balikesir University, Turkey

Elena Velickova,

Saints Cyril and Methodius University

of Skopje, North Macedonia

*Correspondence:

Afam I. O. Jideani

Afam.Jideani@univen.ac.za

Specialty section:

This article was submitted to

Nutrition and Sustainable Diets,

a section of the journal

Frontiers in Sustainable Food Systems

Received: 23 August 2021 Accepted: 22 September 2021

Published: 29 October 2021

Citation:

Mudau N, Ramavhoya K, Onipe OO and Jideani AlO (2021) Plant-and Animal-Based Protein Sources for

Nutritional Boost of Deep-Fried

Dough.

Front. Sustain. Food Syst. 5:763437. doi: 10.3389/fsufs.2021.763437
Flaxseed (Linum usitatissimum L.) is an oilseed that is used in both industry and food production. Flaxseed contains biologically active compounds including linolenic acid, linoleic acid, and lignans. Flaxseed powder (2.5-10\% w/w) and chicken eggs (10-30\% $\mathrm{v} / \mathrm{w}$ ) were substituted in cake wheat flour for fried dough (magwinya) production. The physicochemical properties of the fried dough were determined and compared with the control. There was a significant $(p<0.05)$ increase in moisture, protein, ash, and hardness and a decrease in fat content of fried dough enriched with egg (FDE) and flaxseed powder (FDFX). Enrichment with 30\% (v/w) egg and/or 7.5-10\% flaxseed powder resulted in higher protein, oil reduction, and ash contents compared with the rest of the products. With the current interest in plant-based protein, flaxseed is a good choice of flour-based snacks for consumers without compromise in nutrition.

Keywords: flaxseed powder, chicken egg, magwinya, plant-based protein, animal protein, enrichment

\section{INTRODUCTION}

Protein is formed from amino acids, which are the building blocks of muscle mass that are mostly found in animal products and some plant products. One (1) gram of protein equals 4 calories and is composed of amino acids formed by nitrogen, carbon, hydrogen, oxygen, and sulfur. In bakery products, protein plays a role in the texture of the food by forming gels, stabilizing foams, and emulsions. Chicken eggs are considered human foods for a long time and they are protein-rich containing high-quality nutrients. It is a source of iron, riboflavin, folate, and vitamin B12, D, and E, and contains all nine essential amino acids (Lesnierowski and Stangierski, 2018). Eggs function to enhance the texture and flavor of food products (Vaclavik and Christian, 2014). The egg white (albumen) is an aqueous, faintly straw-tinted, gel-like liquid, consisting of $87.72 \%$ water, $0.85 \%$ carbohydrates, $10.82 \%$ crude protein, $0.19 \%$ fat and $0.42 \%$ ash (Li, 2006; Réhault-Godbert et al., 2019). Egg yolk is a fat-in-water emulsion containing $50 \%$ dry weight; consisting of $65 \%$ lipids, $31 \%$ proteins and $4 \%$ carbohydrates, vitamins, and minerals (Kovacs-Nolan et al., 2005). In dough production, eggs are used to bind other ingredients and strengthen the dough (Indrani and Rao, 2007).

Flaxseed (Linum usitatissimum L.) is an ancient plant that originated in Asia and is now used in both industry and food production (Marie and Ivan, 2017). Flaxseed contains about 8\% crude protein, thereby making it a functional food ingredient (Hussain et al., 2008). Flaxseed has found use in many plant-based foods like an egg replacer due to its rich protein (globulin and albumin) content-speaking to its functionality in baked goods (Bernacchia et al., 2014). Flaxseed is rich in 
fiber (22-26\%) with cellulose, mucilage gums, and lignans as chief fractions. Mucilage gum is a form of polysaccharide that becomes gelatinous on mixing with liquids (Tufail et al., 2020). Flaxseed is also highly acclaimed for its omega-3-fatty acid for plant-based consumers. Of all lipids in flaxseed, 53\% are $\alpha$ linolenic acid (ALA), 17\% linoleic acid (LA), and 19\% oleic acid (Gutte et al., 2015).

Magwinya, also known as "fat cake," is a deep-fried dough product mostly consumed in sub-Saharan Africa (Kearney et al., 2011). The snack is prepared from deep-frying a fermented mixture of refined wheat flour, sugar, salt, yeast, and water. These ingredients provide limited nutrients needed by the body to function well. Eggs are not usually included in the production process in Southern Africa. However, eggs are used in the Belgian version-oliebollen (Ghijselings, 2019). This means that the snack is low in protein. It is characterized as an oily, moist, sweet/salty, crispy golden-brown confectionary. Fat cake can be cut open and stuffed with cheese, mince, and jam or served with fried chips and fish, either as a breakfast with tea or a snack with a soft drink (Onipe et al., 2019). Moreover, primary school learners and the low-income population are the major consumers of this snack (Onipe et al., 2019). Given the burden of malnutrition that plagues low-and middle-income populations of the world, children suffer the most, one of which is protein deficiency (Otiti and Allen, 2021). Egg is a cheap and readily available source of protein for non-vegans, while flaxseed powder is a cheaper protein alternative for plant-based consumers. Hence, this research investigated the effect of egg and flaxseed on the physicochemical properties of fried dough (magwinya).

\section{MATERIALS AND METHODS}

\section{Production of Fried Products}

Cake wheat flour, yeast, brown sugar, salt, sunflower cooking oil, flaxseed powder, and chicken eggs were locally sourced from a supermarket in Limpopo Province, South Africa. Concentrated sulfuric acid, selenium tablet, sodium hydroxide pellets, boric acid, methyl red, and petroleum ether $\left(40-60^{\circ} \mathrm{C}\right)$ were of analytical grade and were used in protein and fat analysis. The chemicals were purchased from Sigma-Aldrich. Fried dough products were produced using the traditional method described by Kwinda et al. (2018) with modifications.

\section{Egg-Enriched Fried Dough (FDE)}

Water and egg mixtures (v/v) were prepared in ratios shown in Table 1. The mixtures were added to dry ingredients (cake wheat flour $-100 \mathrm{~g}$, sugar $-15 \mathrm{~g}$, yeast $-1 \mathrm{~g}$, and salt $-1 \mathrm{~g}$ ). Wet and dry ingredients were mixed until a homogeneous sticky dough was formed.

\section{Flaxseed-Enriched Fried Dough (FDFX)}

Wheat flour was composited with flax seed powder (Table 1). 100 grams each of the composite flour was each combined with yeast $(1 \mathrm{~g})$, salt $(1 \mathrm{~g})$, and sugar $(15 \mathrm{~g})$. To each product, $100 \mathrm{ml}$ of lukewarm water $\left(36.5\right.$ to $\left.40.5^{\circ} \mathrm{C}\right)$ was added to form a homogeneous sticky dough.
The dough products were fermented at ambient temperature $\left(30^{\circ} \mathrm{C}\right)$ and deep-fried in sunflower oil at $180^{\circ} \mathrm{C}$ for $5 \mathrm{~min}$ each. The fried dough was drained and cooled to $25^{\circ} \mathrm{C}$ on absorbent paper until analysis was done. The control product had no eggs or flaxseed powder in its formulation. The frying process and experiments were carried out in triplicate batches.

\section{Methods}

Fried dough products were cooled down to ambient temperature $\left(25^{\circ} \mathrm{C}\right)$, and weights of three products from the three frying batches were collected using a digital weighing balance (Onipe et al., 2018). To ensure data homogeneity, samples with similar weights were randomly selected for the subsequent measurements.

\section{Hardness}

The fried products were cooled for $30 \mathrm{~min}$ after frying and the hardness was measured in triplicate using the approved method 74-09.01 of American Association of Cereal Chemists, 1999. The texture analyzer (TA. XT Plus, Stable Micro Systems Ltd, Godalming, UK) fitted with a 5-kg load cell and a 35$\mathrm{mm}$ cylindrical probe was used for the testing. A return-tostart test was used for measurement with the following settings: $40 \%$ strain, $2 \mathrm{~mm} / \mathrm{s}$, and $1 \mathrm{~mm} / \mathrm{s}$ test and post-test speeds, respectively. The peak positive force $(\mathrm{g})$ in the force-deformation curve was recorded as the hardness value (AACC, Onipe et al., 2018).

\section{Color Determination}

Color analysis was performed using the method of Ndlala et al. (2019) in a ColorFlex 45/0 Spectrophotometer (Hunterlab, Reston, USA) with illuminant D65 and a $10^{\circ} \mathrm{C}$ observer. Three crust and crumb of fried dough products were analyzed for $\mathrm{L}^{*}$ (luminosity), $\mathrm{a}^{*}$ (opposition of colors green and red), and $\mathrm{b}^{*}$ (opposition of colors blue and yellow). Chroma $\left(\mathrm{C}^{*}\right)$, hue $(\mathrm{h})$, and total color difference $(\Delta \mathrm{E})$ were calculated using Eqs 1-3.

$$
\begin{array}{r}
\text { Chroma }=\sqrt{a^{2}+b^{2}} \\
\text { Hue }=\tan ^{-1}\left(\frac{b}{a}\right) \\
\Delta E=\sqrt{\left[(L-L c)^{2}+(a-a c)^{2}+(b-b c)^{2}\right]}
\end{array}
$$

where $L^{*}$ represents lightness from black to white $(0-100)$; $a^{*}$ measures red $(+)$ to green $(-)$; $b^{*}$ measures yellow (+) to blue $(-)$, whereas Lc, ac, and bc represent the color values for the control fried dough (without egg or flaxseed powder). $\Delta \mathrm{E}$ represents the degree of the overall color change of a sample in comparison to color values (Lc, ac, and bc) of the control (Onipe et al., 2018).

\section{Physicochemical Analysis}

Moisture, oil, and ash contents were determined in triplicate using the approved methods 44-15, 30-25.01, and 0801.01 of American Association of Cereal Chemists (1999), respectively. The products were dried, pulverized, and tested for protein content using the Kjeldahl method, according 
TABLE 1 | Formulations for fried dough products.

\begin{tabular}{|c|c|c|c|c|}
\hline Products & Water (ml) & $\mathrm{Egg}(\mathrm{ml})$ & Flaxseed powder (g) & Cake wheat flour (g) \\
\hline Control & 100 & - & - & 100 \\
\hline FDE10 & 90 & 10 & - & 100 \\
\hline FDE20 & 80 & 20 & - & 100 \\
\hline FDE30 & 70 & 30 & - & 100 \\
\hline FDFX2.5 & 100 & - & 2.5 & 97.5 \\
\hline FDFX5.0 & 100 & - & 5.0 & 95 \\
\hline FDFX7.5 & 100 & - & 7.5 & 92.5 \\
\hline FDFX10 & 100 & - & 10 & 90 \\
\hline
\end{tabular}

Yeast (1 g), salt (1 g), and sugar (15g) were uniform in all the products. FDE = egg-enriched fried dough, FDFX = flaxseed powder-enriched fried dough.

to method 955.04 of the Association of Official Analytical Chemists (1995). The percentage nitrogen $\left(\mathrm{N}_{2}\right)$ in protein was multiplied by a factor of 6.25 to get protein content. Total carbohydrate was determined by the difference method using Equation 4.

$\%$ Carbohydrate $=100-(\%$ fat $+\%$ protein $+\%$ ash $+\%$ moisture $)$

\section{Statistical Analysis}

Data were analyzed by one-way analysis of variance. Significant differences $(p<0.05)$ between means were determined by Duncan's multiple range tests (Duncan, 1955). The results were analyzed using a Statistical Package for Social Sciences (SPSS version 23).

\section{RESULTS AND DISCUSSION \\ Hardness of Egg-and Flaxseed-Enriched Fried Dough}

The values for the hardness of FDE and FDFX products ranged from $1,343.37$ to $1,605.24 \mathrm{~g}$ and $1,551.72$ to $1,975.35 \mathrm{~g}$, respectively (Figure 1). The hardness of FDE products was significantly higher than the control, while that of FDFX was significantly lower than the control. Meaning flaxseed caused the fried dough to be softer in comparison to chicken eggs. The results of FDFX showed no linear trend, but a significant reduction $(p<0.05)$ was noted at $2.5,7.5$, and $10 \%$. The differences in the hardness of FDE and FDFX could be accounted for by the variation of water in their formulations. For the FDFX products, the flaxseed powder was worked into the flour, thereby reducing the gluten content (which traps a significant amount of water in a dough matrix) and the amount of water available in the dough. Moreover, the presence of mucilage gum in the flaxseed powder could have caused gas and moisture retention, causing less evaporation of water out of the food during frying, thereby accounting for the softness of FDFX compared to FDE products (Budžaki and Šeruga, 2005; Tufail et al., 2020). Egg yolk is known to improve the richness and tenderness of dough and eating quality, while albumen provides baked products with a good volume and texture (Mine and D'Silva, 2008; Zhao et al., 2010; Van Steertegem et al., 2013).

\section{Color Profile of Egg-and Flaxseed-Enriched Fried Dough Crust and Crumb Color of Egg-Enriched Magwinya}

The crust color profile of FDE products is presented in Table 2. The lightness $\left(\mathrm{L}^{*}\right)$, redness $\left(\mathrm{a}^{*}\right)$, and yellowness values for FDE were in the ranges $31.74-33.03,14.56-17.45$, and 17.6023.71 , respectively. The addition of eggs influenced the crust darkening as observed in the reduction of $\mathrm{L}^{*}$ values with an increase in egg content. This is because amino acids in the egg react with the reducing sugars through the process of Maillard reaction that produces brown color, flavor, and aroma during thermal processing of food (Fayle and Gerrard, 2002; CalderónDomínguez et al., 2005; Onipe et al., 2018). The redness and yellowness of FDE decreased with an increased egg addition. The total color change is the degree of the overall color change of a sample in comparison to the color values of the control (Pathare et al., 2013). The chroma, hue angle, and color change of the FDE decreased with the increase in egg addition compared to control. Hue angle qualitatively describes a product's typical color in terms of real colors such as red or green (Ndlala et al., 2019). The crumb lightness, redness, yellowness, chroma, and $\Delta \mathrm{E}$ of FDE products were significantly higher than those of the control. As expected, the crumb was lighter than the crust because the latter is exposed to the highest heat during frying. The increase in yellowness of FDE compared to control is highly influenced by the yellow color of the egg yolk.

\section{Crust and Crumb Color Profile of Flaxseed-Enriched Fried Dough}

The values of crust color properties for the crust of magwinya were within the following range: $L^{*}(41.44-55.26)$, a* (4.445.43), b* (11.54-17.29), Chroma (12.45-18.12), hue angle (67.97$72.57)$, and $\Delta \mathrm{E}(12.99-19.12)$. Compared to the control, the results of crust color (Table 3 ) indicate a decrease in the lightness, redness, yellowness, and chroma values, and an increase in hue and total color change. Similarly, crumb lightness, yellowness chroma, and hue decreased significantly in FDFX products relative to the control. The redness of the crumb, however, increased markedly - a direct impact of the dark hue of flaxseed powder (Figure 2). Coupled with intense Maillard reaction, these variations in crust color relative to the control are linked to the dark color (brown) of the flaxseed powder. Marpalle et al. (2014) 


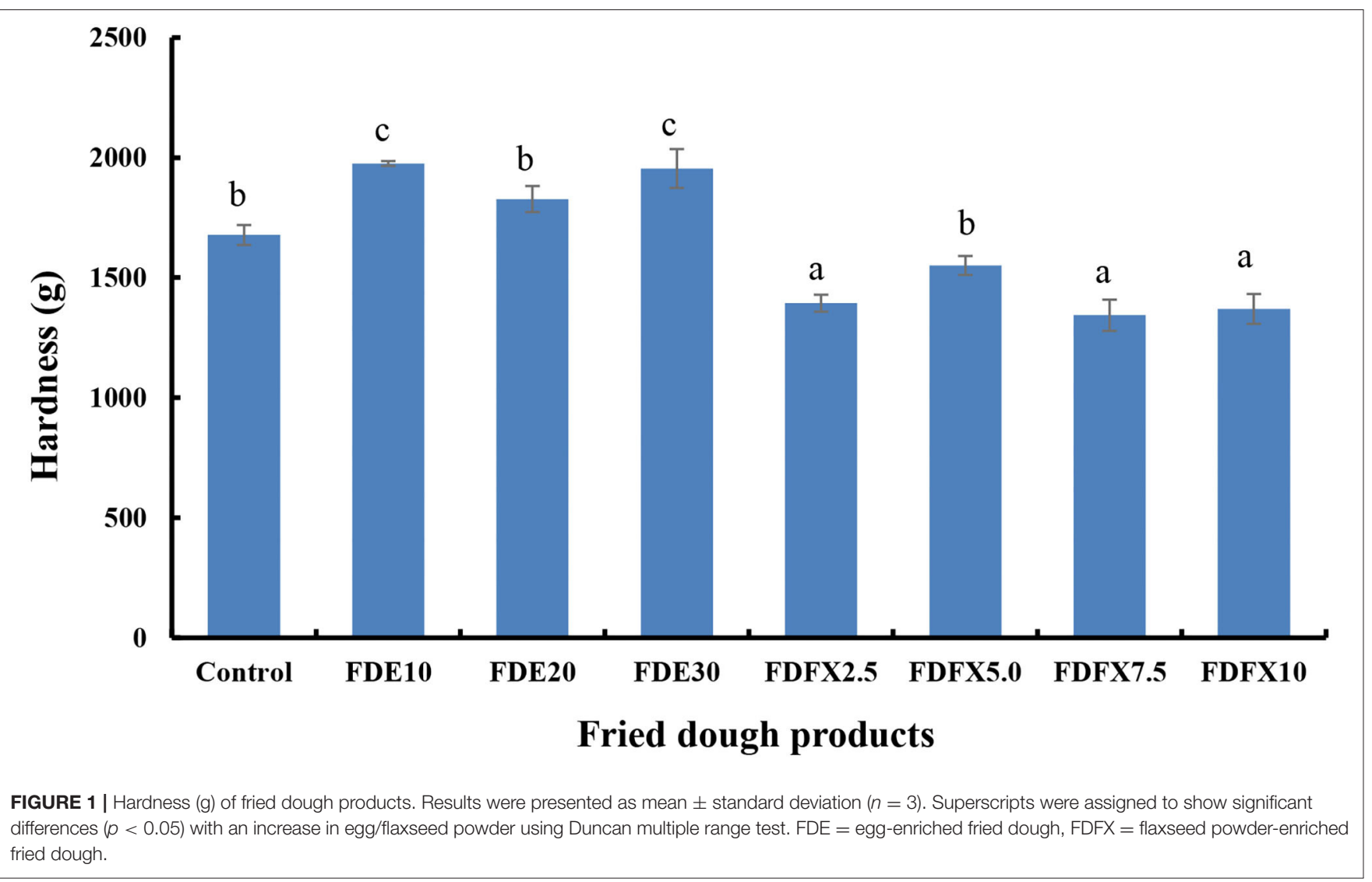

TABLE 2 | Color profile of egg-enriched fried dough.

\begin{tabular}{|c|c|c|c|c|}
\hline Fried products & Control & FDE10 & FDE20 & FDE30 \\
\hline \multicolumn{5}{|l|}{ Crust } \\
\hline$L^{*}$ & $34.51 \pm 1.42^{\mathrm{C}}$ & $35.53 \pm 0.40^{d}$ & $31.74 \pm 1.45^{a}$ & $32.01 \pm 1.55^{\mathrm{b}}$ \\
\hline$a^{*}$ & $17.44 \pm 1.89^{c}$ & $16.86 \pm 1.94^{b}$ & $16.77 \pm 1.57^{a}$ & $17.79 \pm 3.59^{c}$ \\
\hline$b^{*}$ & $21.49 \pm 4.13^{c}$ & $23.71 \pm 4.83^{d}$ & $20.08 \pm 1.81^{b}$ & $17.60 \pm 10.37^{a}$ \\
\hline Chroma & $27.70 \pm 4.32^{\mathrm{c}}$ & $29.45 \pm 5.05^{d}$ & $25.55 \pm 2.39^{b}$ & $23.03 \pm 10.34^{a}$ \\
\hline Hue & $50.70 \pm 2.77^{b}$ & $53.37 \pm 2.39^{c}$ & $51.84 \pm 0.28^{b}$ & $47.77 \pm 8.82^{a}$ \\
\hline$\Delta \mathrm{E}$ & - & $3.74 \pm 1.11^{\mathrm{a}}$ & $5.25 \pm 1.38^{b}$ & $8.88 \pm 3.43^{c}$ \\
\hline \multicolumn{5}{|l|}{ Crumb } \\
\hline$L^{*}$ & $63.01 \pm 1.11^{\mathrm{a}}$ & $66.91 \pm 3.35^{b}$ & $68.39 \pm 2.45^{c}$ & $69.35 \pm 2.70^{c}$ \\
\hline$a^{*}$ & $2.29 \pm 1.12^{\mathrm{a}}$ & $2.89 \pm 0.53^{b}$ & $3.37 \pm 0.18^{c}$ & $3.74 \pm 0.12^{c}$ \\
\hline$b^{*}$ & $21.41 \pm 5.60^{a}$ & $25.91 \pm 2.09^{b}$ & $29.34 \pm 1.42^{c}$ & $30.54 \pm 1.23^{d}$ \\
\hline Chroma & $21.54 \pm 5.68^{a}$ & $26.08 \pm 2.13^{b}$ & $29.53 \pm 1.42^{c}$ & $30.77 \pm 1.28^{d}$ \\
\hline Hue & $83.55 \pm 1.62^{a}$ & $83.68 \pm 0.71^{a}$ & $83.44 \pm 0.35^{a}$ & $83.01 \pm 0.19^{a}$ \\
\hline$\Delta \mathrm{E}$ & - & $8.86 \pm 7.76^{a}$ & $12.49 \pm 11.25^{b}$ & $13.94 \pm 11.39^{c}$ \\
\hline
\end{tabular}

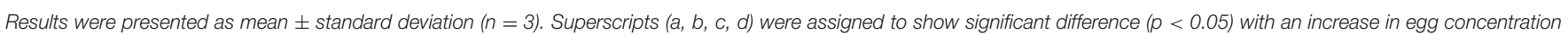
using Duncan's multiple range test. FDE $=$ egg-enriched fried dough.

reported a similar trend in bread enriched with flaxseed. Onipe et al. (2019) reported that wheat bran with medium particle size had a similar effect on the crust and crumb color profile of fried dough. Care must be taken to avoid consumers being put off by the dark color impacted by the brown flaxseed. The decrease in lightness and yellowness with an increase in FP level agrees with the results obtained by Codină et al. (2016) on bread. 
TABLE 3 | Color profile of flaxseed-enriched fried dough

\begin{tabular}{|c|c|c|c|c|c|}
\hline Fried products & Control & FDFX2.5 & FDFX5.0 & FDFX7.5 & FDFX10 \\
\hline \multicolumn{6}{|l|}{ Crust } \\
\hline$L^{*}$ & $34.51 \pm 1.42^{\mathrm{d}}$ & $32.49 \pm 0.09^{b}$ & $32.80 \pm 0.23^{b}$ & $31.81 \pm 0.16^{a}$ & $33.55 \pm 0.20^{c}$ \\
\hline$b^{*}$ & $21.49 \pm 4.13^{\mathrm{d}}$ & $14.30 \pm 0.27^{b}$ & $14.68 \pm 0.22^{b}$ & $13.52 \pm 0.38^{a}$ & $15.94 \pm 0.42^{c}$ \\
\hline Chroma & $27.70 \pm 4.32^{\mathrm{d}}$ & $9.35 \pm 0.06^{b}$ & $10.19 \pm 0.55^{b c}$ & $7.44 \pm 0.26^{a}$ & $10.55 \pm 0.72^{\mathrm{c}}$ \\
\hline \multicolumn{6}{|l|}{ Crumb } \\
\hline$L^{*}$ & $63.01 \pm 1.11^{\mathrm{a}}$ & $55.26 \pm 1.30^{d}$ & $49.77 \pm 1.54^{c}$ & $45.86 \pm 0.24^{b}$ & $41.44 \pm 0.34^{a}$ \\
\hline$a^{*}$ & $2.29 \pm 1.12^{a}$ & $5.43 \pm 0.50^{c}$ & $4.44 \pm 0.07^{b}$ & $4.66 \pm 0.40^{b}$ & $4.91 \pm 0.07^{b c}$ \\
\hline$b^{*}$ & $21.41 \pm 5.60^{d}$ & $17.29 \pm 1.60^{\circ}$ & $13.77 \pm 0.68^{b}$ & $11.54 \pm 1.23^{\mathrm{a}}$ & $12.67 \pm 0.45^{\mathrm{ab}}$ \\
\hline Chroma & $21.54 \pm 5.68^{d}$ & $18.12 \pm 1.68^{\mathrm{C}}$ & $14.47 \pm 0.66^{b}$ & $12.45 \pm 1.29^{\mathrm{a}}$ & $13.59 \pm 0.43^{\mathrm{ab}}$ \\
\hline
\end{tabular}

Results were presented as mean \pm standard deviation $(n=3)$. Superscripts $(a, b, c, d$, ab, bc) were assigned to show significant difference $(p<0.05)$ with an increase in flaxseed powder concentration using Duncan multiple range test. FDFX = flaxseed powder-enriched fried dough.

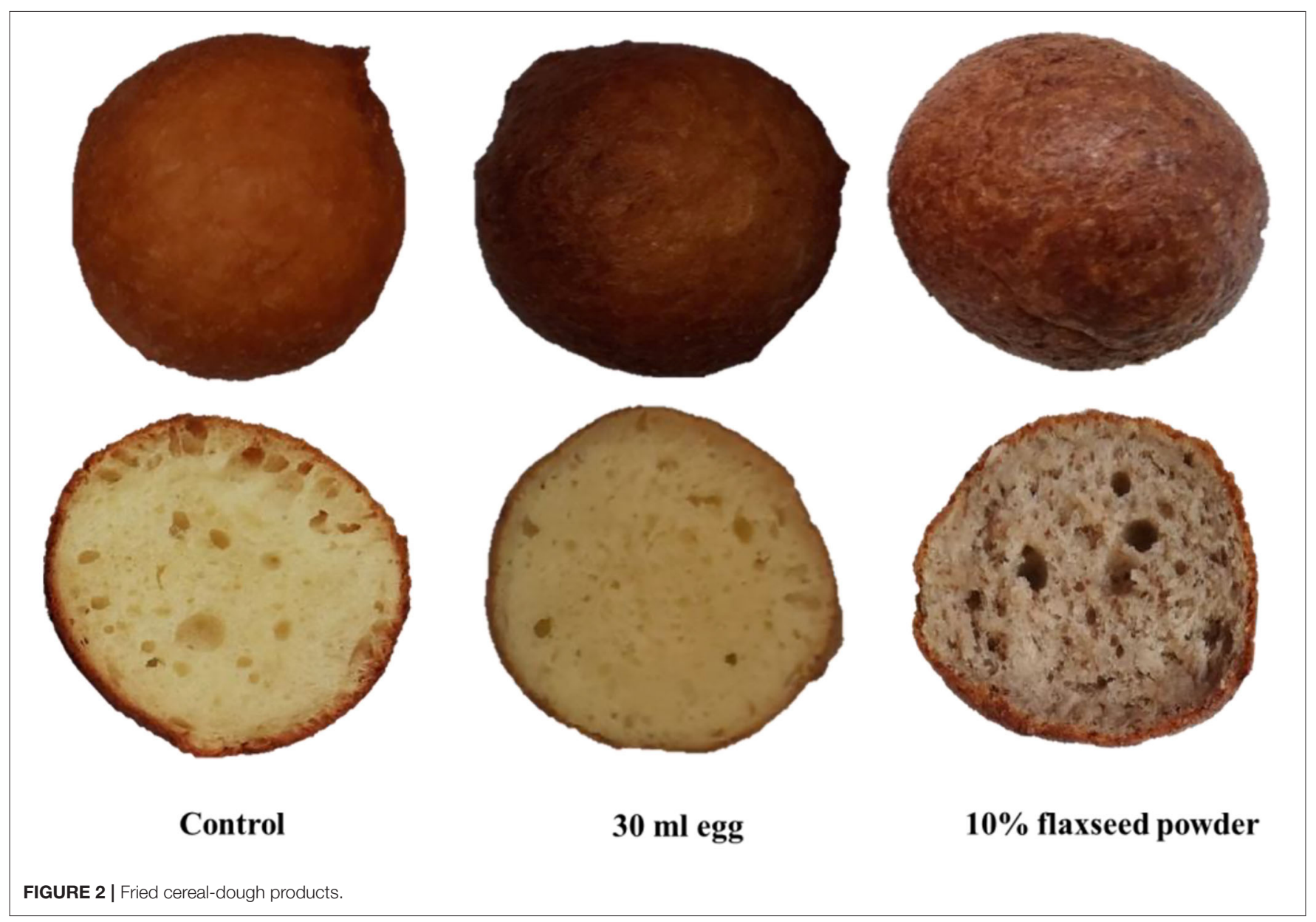




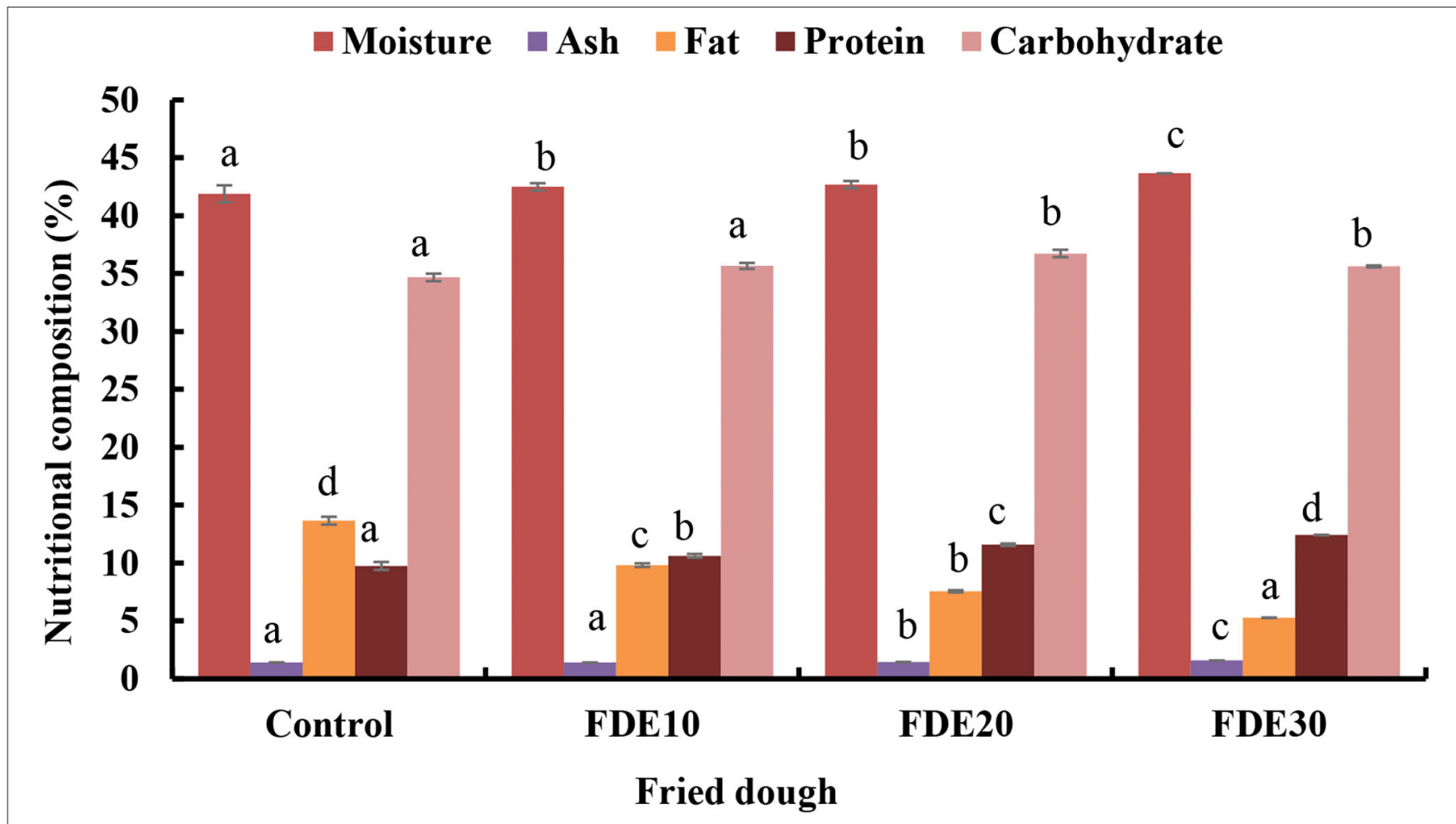

FIGURE 3 | Nutritional composition of egg-enriched fried dough. Results were presented as mean \pm standard deviation ( $n=3$ ). Superscripts were assigned to show significant differences $(p<0.05)$ with an increase in egg in similar bars using Duncan multiple range test. FDE $=$ egg-enriched fried dough.

\section{Moisture Content of Egg-and Flaxseed-Enriched Fried Dough}

The mean moisture values of FDE ranged from 42.49 to $45.10 \%$ (Figure 3) and that of FDFX ranged from 42.00 to $43.33 \%$ and were slightly higher than the control at $41.89 \%$ (Figure 4 ). The increased moisture content of FDE can be attributed to the ability of eggs to bind with other ingredients during the formation of dough. The results showed that the incorporation of eggs improved the moisture content of magwinya, albeit small. There was no significant difference $(p<0.05)$ in the moisture content of the products with different amounts of flaxseed powder, but the moisture content of control was significantly low. The increase in moisture content of FDFX products may be due to the fiber content of flaxseed powder, which increased high moisture retention (Ganorkar and Jain, 2014). Similar results were reported by Xu et al. (2014) where the moisture content of bread markedly increased with the increase in flaxseed flour.

\section{Ash Content of Egg-and Flaxseed-Enriched Fried Dough}

The ash content of FDE ranged from 1.40 to $1.58 \%$ (Figure 3) and FDFX ranged from 1.56 to $1.97 \%$ (Figure 4) and were all significantly higher than control (1.41\%). An increasing linear trend $(p<0.05)$ was observed for the ash content of FDE and FDFX products with an increase in egg and flaxseed powder concentration. The increase in ash content in both FBE and FDE shows that egg and flaxseed powder increased the mineral content of fried dough compared to control. This is because of the high mineral content of eggs (Haytowitz and Pehrsson, 2018) and flaxseeds (Codinǎ et al., 2016). Masoodi and Bashir (2012) reported a $69 \%$ increase in the ash content of biscuits enriched with $10 \%$ flaxseed powder.

\section{Fat Content of Egg-and Flaxseed-Enriched Fried Dough}

The fat content of FDE products ranged from 5.27 to $9.82 \%$ (Figure 3), while FDFX ranged from 6.08 to $9.41 \%$ (Figure 4). The fat content of FDE and FDFX products was significantly lower than control (13.66\%). During deep-frying, the heat evaporates moisture out of the products, while oil penetrates inside the products (Krokida et al., 2000; Budžaki and Šeruga, 2005). Due to the consistency of the control dough, large gas cells are formed during the fermentation process, thereby creating more pores for oil uptake during frying and higher fat content in the control products compared to other products (Ivorra et al., 2014). Egg binds the ingredients together during dough mixing, thereby increasing the dough strength and its elasticity, which may have impeded moisture loss and contributed to the reduced fat content in FDE products (Indrani and Rao, 2007; Van Steertegem et al., 2013). The least fat contents for FDE and FDFX were recorded at 30\% egg and 10\% flaxseed powder addition, showing that both additives reduced the fat content of the fried dough. Contrary to what other researchers have reported that flaxseed increased the fat content of other products 


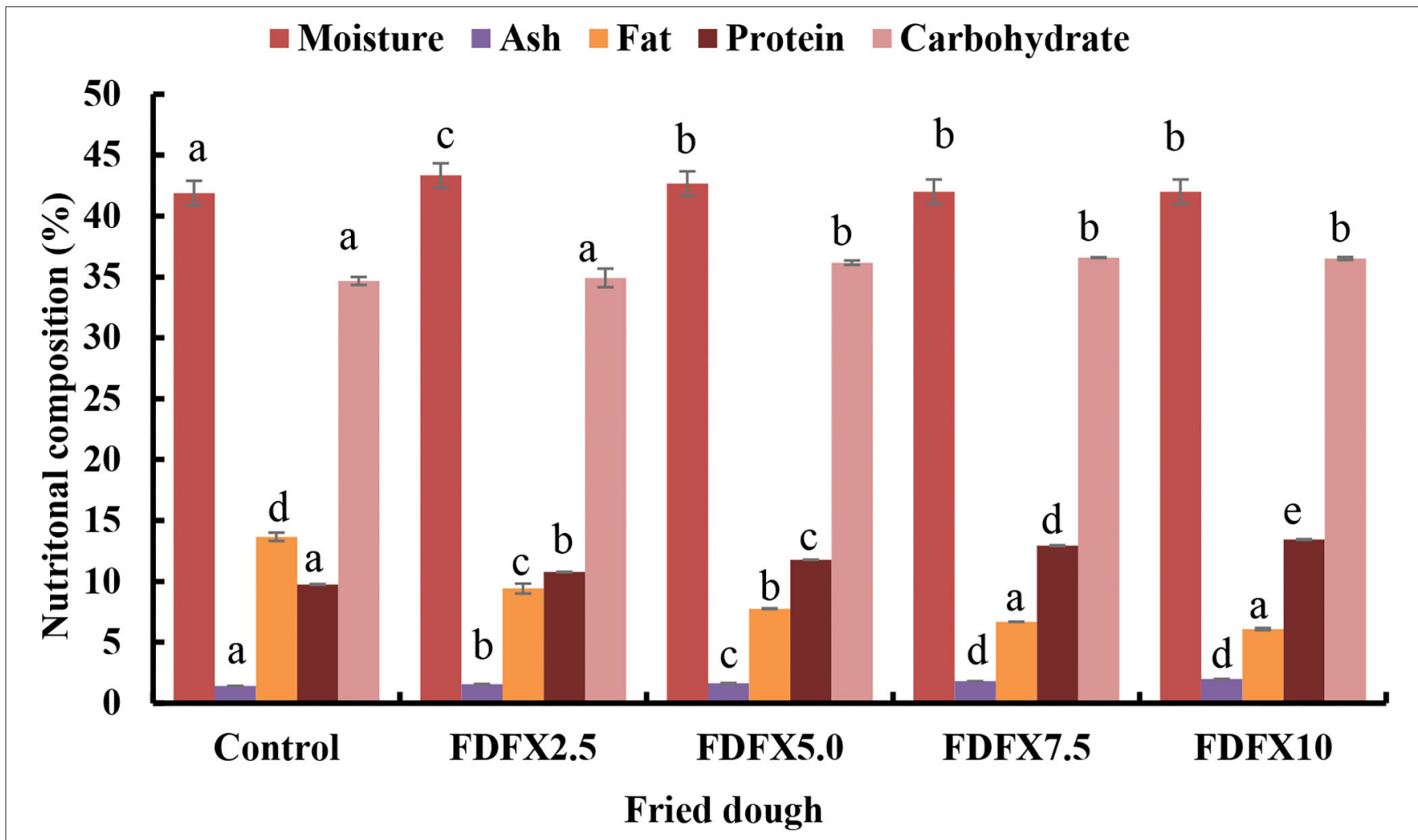

FIGURE 4 | Nutritional composition of flaxseed-enriched fried dough. Results were presented as mean \pm standard deviation ( $n=3$ ). Superscripts were assigned to show significant differences $(p<0.05)$ with an increase in egg in similar bars using Duncan multiple range test. FDFX $=$ flaxseed-enriched fried dough.

like cookies and bread (Masoodi and Bashir 2012), the use of flaxseed in our product resulted in reduced fat content. This may be because of the high-water retention capacity of flaxseed, which may have led to a minimal replacement of water with oil, hence the decrease in fat content (Mellema, 2003; Kwinda et al., 2018).

\section{Protein Content of Egg-and Flaxseed-Enriched Fried Dough}

The protein contents of the FDE products ranged from 10.63 to $12.42 \%$ (Figure 3), and FDFX ranged from 10.77 to $13.44 \%$ (Figure 4) and were all significantly higher than the control (9.75\%). The highest protein values were found in FDE30 and FDFX10. This shows that the addition of eggs and/or flaxseed increased the protein content of magwinya. This is because an egg contains about $12.5 \%$ protein from both albumen and yolk (Seuss-Baum and Francoise, 2011) and the rich protein content of flaxseed (Hussain et al., 2008; Tufail et al., 2020). Other authors have reported a significant increase in the protein content of biscuits (Masoodi and Bashir, 2012) and cookies (Kaur et al., 2019) enriched with flaxseed. The protein contents of whole wheat-based bread increased with the increased addition of chia seed flour (Sayed-Ahmad et al., 2018).

\section{Carbohydrate Content of Egg-and Flaxseed-Enriched Fried Dough}

As shown in Figures 3, 4 carbohydrate content increased significantly with an increase in egg addition from $20 \%$ and flaxseed powder from $5 \%$ flaxseed. The polysaccharide content of flaxseed could have contributed to this increase. Since carbohydrate content was calculated using the difference method, the decrease in fat content could have encouraged the increase in the percentage of carbohydrates. Marpalle et al. (2014) reported a significant decrease in carbohydrate percentage with an increase in flaxseed flour on functional bread.

\section{CONCLUSION}

Supplementing the formulation of fried dough with eggs and flaxseed powder positively influenced the physicochemical properties of the fried dough products. Increased levels of egg and flaxseed powder increased the moisture, ash, and protein content while reducing fat content. The protein contents of FDE and FDFX products were comparable, but the highest level was reported at $10 \%$ flaxseed supplementation. Flaxseed powder had no significant impact on the hardness of the fried dough, but it decreased the lightness, redness, and yellowness of the product. The effect on color may repel consumers, but a consumer acceptability test is recommended to confirm or 
reject this assumption. Further research is recommended on the impact of egg and flaxseed powder on the microstructure, mineral content, and rheological properties of the dough. The findings of this research show that nutritious low-fat fried dough can be produced from plant and animal protein sources to cater for consumers on both diets.

\section{DATA AVAILABILITY STATEMENT}

The original contributions presented in the study are included in the article, further inquiries can be directed to the corresponding author.

\section{REFERENCES}

American Association of Cereal Chemists (1999). Approved methods of American Association of Cereal Chemists. Available online at http://methods.aaccnet.org/ toc.aspx (accessed September 15, 2020).

Association of Official Analytical Chemists (AOAC) (1995). Official Methods of Analysis, 16th Edn. Gaithersburg, MD: AOAC International.

Bernacchia, R., Preti, R., and Vinci, G. (2014). Chemical composition and health benefits of flaxseed. Austin J. Nutr. Food Sci. 2, 1045-1053.

Budžaki, S., and Šeruga, B. (2005). Moisture loss and oil uptake during deep-fat frying of "Kroštula" dough. Eur. Food Res. Technol. 220, 90-95. doi: $10.1007 / \mathrm{s} 00217-004-1058-3$

Calderón-Domínguez, G., Farrera-Rebollo, R., Arana-Errasquín, R., and MoraEscobedo, R. (2005). The effect of varying the mixing formula on the quality of a yeast sweet bread on the process conditions, as studied by surface response methodology. Int. J. Food Sci. Technol. 40, 157-164. doi: $10.1111 / j .1365-2621.2004 .00926 . x$

Codină, G. G., Mironeasa, S., and Todosi-Sănduleac, E. (2016). Studies regarding the influence of brown flaxseed flour addition in wheat flour of very good quality for bread making on bread quality. Bull. UASVM Food Sci. Technol. 73, 70-76. doi: 10.15835/buasvmen-fst:12148

Duncan, D. B. (1955). Multiple range and multiple $F$ tests. Biometrics 11, 1-42. doi: $10.2307 / 3001478$

Fayle, S. E., and Gerrard, J. A. (2002). The Maillard Reaction. Cambridge: Royal Society of Chemistry.

Ganorkar, P. M., and Jain, R. K. (2014). Effect of flaxseed incorporation on physical, sensorial, textural and chemical attributes of cookies. Int. Food Res. J. 21, $1515-1521$.

Ghijselings (2019). Physicochemical properties and hyperspectral imaging of fried cereal doughs-magwinya and oliebollen (Bachelor's thesis). UC LuevenLimburg, Brabant, Belgium.

Gutte, K. B., Sahoo, A. K., and Ranveer, R. C. (2015). Bioactive components of flaxseed and its health benefits. Int. J. Pharm. Sci. Rev. Res. 31, 42-51.

Haytowitz, D. B., and Pehrsson, P. R. (2018). USDA's National Food and Nutrient Analysis Program (NFNAP) produces high-quality data for USDA food composition database: two decades of collaboration. Food Chem. 238, 134-138. doi: 10.1016/j.foodchem.2016.11.082

Hussain, S., Anjum, F. M., Butt, M. S., and Sheikh, M. A. (2008). Chemical composition and functional properties of flaxseed (Linum usitatissimum) flour. Sarhad J. Agric. 24, 649-653.

Indrani, D., and Rao, G. V. (2007). Rheological characteristics of wheat flour dough as influenced by ingredients of parotta. J. Food Eng. 79, 100-105. doi: 10.1016/j.jfoodeng.2006.01.033

Ivorra, E., Amat, S. V., Sánchez, A. J., Barat, J. M., and Grau, R. (2014). Continuous monitoring of bread dough fermentation using a $3 \mathrm{D}$ vision structured light technique. J. Food Eng. 130, 8-13. doi: 10.1016/j.jfoodeng.2013.12.031

Kaur, P., Sharma, P., Kumar, V., Panghal, A., Kaur, J., and Gat, Y. (2019). Effect of addition of flaxseed flour on phytochemical, physicochemical, nutritional, and textural properties of cookies. J. Saudi Soc. Agric. Sci. 18, 372-377. doi: 10.1016/j.jssas.2017.12.004

\section{AUTHOR CONTRIBUTIONS}

OOO and AIOJ supervised the project and defined the objective of the article. NM and KR collected and analyzed the data. OOO drafted and AIOJ proofread the manuscript. All authors participated in the interpretation of results.

\section{FUNDING}

The research reported in this publication was supported by the DST-NRF Center of Excellence in Food Security SMART Foods Project (Project ID: 160201).

Kearney, J., Oldewage-Theron, W., and Napier, C. (2011). Development and processing of a novel food product for a school feeding project in South Africa. Afr. J. Hosp. Tour. Leis. 1, 4-7.

Kovacs-Nolan, J., Phillips, M., and Mine, Y. (2005). Advances in the value of eggs and egg components for human health. Review. J. Agric. Food Chem. 53:8421. doi: 10.1021/jf050964f

Krokida, M. K., Oreopoulou, V., and Maroulis, Z. B. (2000). Effect of frying conditions on shrinkage and porosity of fried potatoes. J. Food Eng. 43, 147-154. doi: 10.1016/S0260-8774(99)0 0143-0

Kwinda, O., Onipe, O. O., and Jideani, A. I. O. (2018). The effect of oat bran and psyllium husk fibre on oil reduction and some physicochemical properties of magwinya-a deep-fried dough, CyTA. J. Food 16, 247-254. doi: 10.1080/19476337.2017.1389991

Lesnierowski, G., and Stangierski, J. (2018). What's new in chicken egg research and technology for human health promotion? A review. Trends Food Sci. Technol. 71, 46-51. doi: 10.1016/j.tifs.2017.10.022

$\mathrm{Li}, \mathrm{S}$. J. (2006). Structural details at the active site of hen egg-white lysozyme with di-and trivalent metal ions. Biopolymers 81, 1196-1199. doi: 10.1002/bip.20367

Marie, H., and Ivan, Š. (2017). Rheological Characteristics of composite flour with linseed fibre-relationship to bread quality. Czech J. Food Sci. 35, 424-431. doi: 10.17221/450/2016-CJFS

Marpalle, P., Sonawane, S. K., and Arya, S. S. (2014). Effect of flaxseed flour addition on physicochemical and sensory properties of functional bread. LWT-Food Sci. Technol. 58, 614-619. doi: 10.1016/j.lwt.2014. 04.003

Masoodi, L., and Bashir, V. (2012). Fortification of biscuit with flaxseed: biscuit production and quality evaluation. IOSR J. Environ. Sci. Toxicol. Food Technol. 1, 6-9. doi: 10.9790/2402-0150609

Mellema, M. (2003). Mechanism and reduction of fat uptake in deep-fat fried foods. Trends Food Sci. Technol. 14, 364-373. doi: 10.1016/S0924-2244(03)00050-5

Mine, Y., and D'Silva, I. (2008). "Bioactive components in egg white," in Egg Bioscience and Biotechnology, ed Y. Mine (Hoboken, NJ: Wiley and Sons publication), 141-184. doi: 10.1002/9780470181249.ch4

Ndlala, F. N., Onipe, O. O., Mokhele, T. M., Anyasi, T. A., and Jideani, A. I. O. (2019). Effect of wheat bran incorporation on the physical and sensory properties of a South African cereal fried dough. Food 8, 559-573. doi: 10.3390/foods8110559

Onipe, O. O., Beswa, D., and Jideani, A. I. O. (2019). The socioeconomic benefits, production and consumption statistics of magwinya in Limpopo province, South Africa. Afr. J. Food, Agric. Nutr. Dev. 19, 15007-15028. doi: 10.18697/ajfand.87.18030

Onipe, O. O., Beswa, D., Jideani, V. A., and Jideani, A. I. O. (2018). Optimization of processing conditions for oil reduction of magwinya (a deep-fried cereal dough). Afr. J. Sci. Technol. Innov. Dev. 10, 209-218. doi: 10.1080/20421338.2018.1440920

Otiti, M. I., and Allen, S. J. (2021). Severe acute malnutrition in lowand middle-income countries. Paediatr. Child Health 31, 301-307. doi: 10.1016/j.paed.2021.05.001 
Pathare, P. B., Opara, U. L., and Al-Said, F. A.-J. (2013). Color measurement and analysis in fresh and processed foods: a review. Food Bioproc. Tech. 6, 36-60. doi: 10.1007/s11947-012-0867-9

Réhault-Godbert, S., Guyot, N., and Nys, Y. (2019). The golden egg: nutritional value, bioactivities, and emerging benefits for human health. Nutrition 11:684. doi: 10.3390/nu11030684

Sayed-Ahmad, B., Talou, T., Straumite, E., Sabovics, M., Kruma, Z., Saad, Z., et al. (2018). Evaluation of nutritional and technological attributes of whole wheat-based bread fortified with chia flour. J. Food 7:135. doi: 10.3390/foods70 90135

Seuss-Baum, I., and Francoise, N. (2011). "The nutritional quality of eggs," in Improving the Safety and Quality of Eggs and Egg Products, eds F. van Immerseel, F. Y. Nys, and M. Bain (Cambridge, GB: Woodhead Publishing Ltd), 201-236. doi: 10.1533/9780857093929.3.201

Tufail, T., Riaz, M., Arshad, M. U., Gilani, S. A., Ain, H. B. U., Khursheed, T., et al. (2020). Functional and nutraceutical scenario of flaxseed and sesame: a review. Int. J. Biosci. 17, 173-190. doi: 10.12692/ijb/17.3.1 73-190

Vaclavik, V. A., and Christian, E. W. (2014). "Eggs and egg products," in Essentials of Food Science, ed D. R. Heldman (New York, NY: Springer), 179-199. doi: 10.1007/978-1-4614-9138-5_10

Van Steertegem, B., Pareyt, B., Brijs, K., and Delcour, J. A. (2013). The effects of fresh eggs, egg white, and egg yolk, separately and in combination with salt, on mixogram properties. Cereal Chem. 90, 269-272. doi: 10.1094/CCHEM-11-12-0160-N
Xu, Y., Hall, I. I. I., C. A., and Manthey, F. A. (2014). Effect of flaxseed flour on rheological properties of wheat flour dough and bread characteristics. J. Food Res. 3, 83-91. doi: 10.5539/jfr.v3n6p83

Zhao, X., Shi-Jian, D., Tao, G., Xu, R., Wang, M., Reuhs, B., et al. (2010). Influence of phospholipase A2 (PLA2)-treated dried egg yolk on wheat dough rheological properties. LWT-Food Sci. Tech. 43, 45-51. doi: 10.1016/j.lwt.2009.06.027

Conflict of Interest: The authors declare that the research was conducted in the absence of any commercial or financial relationships that could be construed as a potential conflict of interest.

Publisher's Note: All claims expressed in this article are solely those of the authors and do not necessarily represent those of their affiliated organizations, or those of the publisher, the editors and the reviewers. Any product that may be evaluated in this article, or claim that may be made by its manufacturer, is not guaranteed or endorsed by the publisher.

Copyright (C) 2021 Mudau, Ramavhoya, Onipe and Jideani. This is an open-access article distributed under the terms of the Creative Commons Attribution License (CC BY). The use, distribution or reproduction in other forums is permitted, provided the original author(s) and the copyright owner(s) are credited and that the original publication in this journal is cited, in accordance with accepted academic practice. No use, distribution or reproduction is permitted which does not comply with these terms. 